\title{
Participação, Pluralismo e Autonomia das Lideranças: Partido dos Trabalhadores, Frente Ampla e Partido Socialista do Chile em Perspectiva Comparada
}

\author{
Carlos Ranulfo Melo ${ }^{1}$ \\ 1Professor do Departamento de Ciência Política da Faculdade de Filosofia e Ciências Humanas da \\ Universidade Federal de Minas Gerais (FAFICH-UFMG). Minas Gerais, MG, Brasil. \\ E-mail: carlos.ranulfo@yahoo.com.br
}

\section{INTRODUÇÃO}

F 2017 , o vice-presidente do Uruguai, senador Raul Sendic, da EFrente Ampla (FA), se viu confrontado com denúncias de mau uso de cartões corporativos. O Tribunal de Conduta Política de seu partido qualificou o comportamento como "inaceitável". Sendic renunciou ao posto e à sua cadeira no Senado e seus direitos como filiado foram suspensos até $2020^{1}$. O episódio evidencia que, mesmo após três décadas de controle da prefeitura de Montevideo e três mandatos presidenciais, o grau de autonomia das lideranças mantém-se baixo no partido. No Partido dos Trabalhadores (PT), mesmo nas crises que se seguiram ao "mensalão" (2005) e ao desvio de recursos da Petrobrás, descoberto pela operação Lava-jato em 2014, nenhum dirigente foi responsabilizado - um restrito grupo de líderes próximos a Lula operava em um contexto decisório à parte, fora do alcance de qualquer instrumento de controle e prestação de contas. No Partido Socialista do Chile (PS), em 2017, o Comitê Central cancelou uma prévia definida em Congresso, destinada a escolher o candidato do partido à Presidência da República e para a qual dois postulantes se apresentavam, sem que se registrasse qualquer reação expressiva no partido. Os socialistas chilenos acostumaram-se a uma dinâmica de acordos entre suas elites, com uma quase nula influência das bases nas decisões tomadas. 
Este artigo compara FA, PT e PS e mostra porque no primeiro caso os líderes tiveram que conduzir o partido com baixo grau de autonomia decisória enquanto nos demais a margem de manobra das lideranças se ampliou. A análise segue duas sugestões feitas por Lijphart (1971) para minimizar os problemas típicos da utilização da comparação como método: focar a análise nas variáveis consideradas chave para o fenômeno em estudo e escolher casos comparáveis. Ainda que não se possa levar muito longe o argumento - quaisquer que sejam as sociedades, a ideia de que possam ser consideradas idênticas em uma série de aspectos, exceto em um, não é factível - a escolha de casos similares permite que um conjunto de variáveis possa ser considerado constante.

Três pontos foram levados em conta na escolha dos partidos aqui comparados. Em primeiro lugar, é nas organizações de esquerda que a participação é mais saliente e pode ensejar mecanismos de controle sobre as lideranças. Em segundo lugar, foi levada em conta a relativa similaridade entre os três partidos no que se refere ao grau de institucionalização. Neste aspecto eles se diferenciam de outros atores situados à esquerda que também chegaram à Presidência de seus países, como os casos do Partido Justicialista (PJ) na Argentina, do Movimento Pátria Altiva e Soberana (PAIS) no Equador, do Movimento V República (MVR) na Venezuela e do Movimento ao Socialismo (MAS) na Bolívia. Finalmente, a similaridade entre PT, FA e PS se torna evidente quando levamos em conta sua origem e trajetória: a) os três são "primos distantes" dos partidos de massa europeus e enfrentaram os dilemas inerentes a uma transformação em máquinas "eleitorais-profissionais"; b) suas lideranças passaram pela experiência das ditaduras militares, vivenciaram a crise do socialismo e puderam usufruir de um aprendizado que contribuiu para a moderação e aceitação das regras do jogo representativo; e c) sua chegada ao governo se deu sem rupturas e seus mandatos se desenvolveram em contextos de estabilidade, instituições robustas, presença de uma oposição de centro e de direita no Congresso e com um grau de mobilização e protesto relativamente baixo (Melo, 2016) ${ }^{2}$.

O argumento desenvolvido é de que a diferença no grau de autonomia das lideranças pode ser explicada por quatro fatores vinculados ao desenvolvimento organizacional dos partidos: a) a influência das bases no processo decisório; b) o balanço de poder entre os diversos grupos no interior de cada partido; c) a distância ideológica/programática entre esses grupos; e d) a existência de uma única liderança 
incontestavelmente reconhecida como capaz de servir como ponto de referência e aglutinação do partido. Mais especificamente, o que se pretende mostrar é que, em cada partido, a margem de manobra dos líderes varia em função da maneira como esses fatores se combinam. A primeira seção apresenta o esquema analítico e os fatores explicativos. Na segunda, é discutida a importância do momento fundacional de cada partido. As duas seções subsequentes são dedicadas ao desenvolvimento organizacional de cada um dos casos: uma se dedica à relação entre bases e líderes e outra ao jogo entre as correntes internas. Na conclusão, o argumento é sumarizado e são evidenciados os resultados da comparação levada a efeito.

\section{PARTIDOS POLÍTICOS E AUTONOMIA DAS LIDERANÇAS}

A capacidade dos líderes de traçar estratégias adequadas ao ambiente que operam, e de alterá-las diante de novas circunstâncias, é um dos fatores que condicionam o sucesso ou fracasso de seus partidos. Segundo Kitschelt (1994), os partidos onde uma liderança autônoma assenta-se sobre uma estrutura orgânica fluida possuem maior capacidade de adaptação - o que permitiria responder aos influxos vindos da sociedade e/ ou operar mudanças de cima para baixo. No outro extremo, partidos que combinam uma liderança dotada de baixa autonomia com uma estrutura orgânica densa teriam dificuldade de se modificar de fora para dentro - dada a resiliência estrutural face às mudanças - e também de cima para baixo - em função da operação de instrumentos de controle e/ou atores de veto. Analisando a trajetória do peronismo, Levistsky (2005) argumenta que partidos precariamente institucionalizados - dotados de estrutura interna fluida e carentes de uma organização burocrática, enquanto conduzidos de forma centralizada - reagem mais rapidamente a momentos de crise graças à maior flexibilidade estratégica de seus dirigentes. Por fim, para Panebianco (2005), partidos que se consolidam institucionalmente transitam de uma fase em que os líderes operam com ampla liberdade, para uma outra na qual a margem de manobra é reduzida devido às constrições organizativas.

Na comparação aqui levada a efeito, dois pontos merecem destaque. Em primeiro lugar, importa a fundação de cada partido, quando os líderes atuam com maior liberdade, definem regras e delineiam os traços identitários da organização. Escolhas feitas nesse período informam os caminhos a seguir e possuem impacto sobre os movimentos posteriores. Ainda neste aspecto cabe recorrer a Panebianco (2005), 
para quem a maneira como se constitui o partido - por penetração ou difusão territorial - influencia seu desenvolvimento posterior. Em segundo lugar, deve-se levar em conta a sequência de eventos. Partidos evoluem em resposta a um ambiente cambiante e a estratégias políticas dos diversos atores; dessa forma, ainda que as marcas de origem se mantenham por longo período, a fundação não possui um caráter determinista. $\mathrm{O}$ desenvolvimento organizacional - materializado em decisões sobre os mecanismos de escolha de dirigentes e candidatos, nas formas de participação, regulamentação das tendências e processos decisórios - gera eventos que reforçam ou não as características iniciais e, dessa forma, resolvem eventuais ambiguidades presentes na fundação.

Para explicar o maior ou menor grau de autonomia das lideranças de cada partido será preciso analisar o conflito pelo poder entre os diferentes agentes que o integram. Com este objetivo quatro fatores são levados em conta. O primeiro deles é relativo aos jogos verticais e avalia a influência das bases no processo decisório. O segundo remete aos jogos horizontais e busca captar o balanço de poder entre os diversos grupos no interior de cada partido. A conexão aqui é imediata: o pluralismo interno, em contraposição a um contexto de hegemonia, amplia as opções dos filiados na relação com as lideranças. Outros dois fatores permitem uma melhor qualificação do impacto dos jogos horizontais. Argumenta-se que: a) o impacto do pluralismo interno varia a depender distância ideológica/programática entre os grupos que compõem o partido, e que b) a existência de uma única liderança incontestavelmente reconhecida como capaz de servir como ponto de referência e aglutinação do partido tende a reforçar situações de hegemonia.

Em suma, o argumento é que os líderes partidários terão maior autonomia quando: a) as bases partidárias deixam de ter influência sobre o processo decisório - direta no caso de militantes ou indireta no caso de movimentos sociais; b) prevalece uma situação de hegemonia interna e apenas um grupo controla por longo período as principais zonas de incerteza do partido; c) os maiores grupos internos compartilham de concepções ideológicas / programáticas semelhantes; e d) a trajetória do partido confunde-se com a de uma única liderança. 


\section{A FUNDAÇÃO IMPORTA}

Ainda que não tenha um caráter determinista, a maneira como se realiza a fundação de um partido importa. Trata-se de um momento de liberdade; nos limites de certo contexto, são muitas as possibilidades abertas aos líderes. Escolhas devem ser feitas; e seu impacto sobre o perfil identitário da organização, bem como sobre os caminhos a seguir, pode ser duradouro.

A fundação da FA, foi precedida por dois eventos marcantes. Entre 1964 e 1966 o movimento sindical uruguaio conseguiu superar sua fragmentação e se unificou em torno da Confederação Nacional dos Trabalhadores (CNT). Os partidos de esquerda, por sua vez, contavam com o aprendizado do início daquela década, quando conviveram duas experiências frentistas: uma capitaneada pelos socialistas (Unidade Popular) e outra pelos comunistas (Frente Izquierda de Liberación FIDEL). O desempenho eleitoral à época mostrou que para enfrentar os partidos tradicionais seria preciso ir além (Moraes e Lujan, 2016).

Ao surgir, em 1971, a FA marcou a confluência entre um movimento sindical forte e unificado (Lanzaro, 2001; 2011) e um rol de setores políticos que ia de organizações de esquerda a grupos oriundos dos partidos Colorado e Nacional. Nos dizeres de suas lideranças, o partido nascia com "sus dos patas"3: para além de uma coalizão entre grupos políticos, a ideia era lançar um "movimento frenteamplista" aberto à participação de indivíduos e setores da sociedade civil. O processo de constituição se fez por "difusão territorial", e a convergência de organizações preexistentes deu origem a uma estrutura de tipo consociativo, alicerçada na garantia estatutária de participação dos grupos fundadores nos órgãos diretivos, nas regras para adesão de novos agrupamentos e na determinação de que as bases programáticas do "acordo político" então firmado só poderiam ser alteradas por unanimidade (Melo, 2016). A diversidade dos principais grupos fundadores - Partido Demócrata Cristiano (PDC), Movimiento por el Gobierno del Pueblo (MGP, oriundo do Partido Colorado), Partido Comunista do Uruguai (PCU), Partido Socialista (PSU) e Movimiento Patria Grande (egresso do Partido Nacional) - teve impacto sobre o programa e a própria denominação adotada. O partido se unificou em torno de uma plataforma "anti-imperialista" e "anti-monopolista", ainda que não socialista, lastreada em duas tradições presentes na política uruguaia: o batlismo, com sua ênfase no papel do Estado 
como promotor do desenvolvimento econômico e social, e o artiguismo, com sua vocação libertária e independentista (Yafeé, 2005). Ainda hoje, segundo o deputado Alejandro Sanchéz (Movimiento de Participación Popular - MPP), qualquer tentativa de definir ideologicamente a FA provocaria o seu fim. Por outro lado, de acordo com o senador Rafael Michelini (Nuevo Espacio - NE), a criação de uma frente "ampla" em vez de "popular" é explicada pela força do PDC e do $\mathrm{MGP}^{4}$.

Fundado em 1980, o PT foi o estuário dos mais diversos tipos de ativismo social, ainda que não contasse com um movimento sindical nacionalmente organizado, mas apenas com um "novo sindicalismo" minoritário em um cenário ainda dominado pelos "pelegos". Por outro lado, as condições necessárias para a constituição de uma "frente" não existiam. Nas discussões posteriores ao anúncio da reforma partidária, em 1978, as alternativas eram a atuação no Movimento Democrático Brasileiro (MDB; defendida pelos comunistas), a criação de um "partido popular" (posição assumida por FHC), a retomada do Partido Trabalhista Brasileiro (PTB; opção preferida por Brizola) e a criação de um outro partido dos trabalhadores. A onda de greves de 1978/79 fortaleceu a percepção de Lula e lideranças de que havia condições de impulsionar a organização autônoma dos trabalhadores por meio de um partido (Keck, 1991).

A criação do PT se deu por um processo de "penetração territorial", ainda que tal caracterização deva ser matizada. $\mathrm{O}$ núcleo fundador - baseado em São Paulo, ancorado no si0 ndicalismo do ABC e ao qual se agregaram intelectuais e setores vinculados às Comunidades Eclesiais de Base da Igreja Católica - só se assumiu como um campo organizado três anos após a fundação. Ademais, para além da ênfase discursiva na relação do partido com as lutas sociais e na necessidade de participação política dos trabalhadores - voltada para uma democracia "participativa" e uma organização partidária tributária de uma concepção basista - tal núcleo não possuía uma definição ideológica mais precisa. Como não existiam recursos suficientes para organizar o partido com a rapidez requerida pela legislação, os "fundadores" aceitaram que o processo ocorresse de acordo com a natureza do(s) grupo(s) que assumisse(m) a empreitada nos estados, o que permitiu maior liberdade de ação aos agrupamentos de esquerda marxista que aderiram ao projeto (Amaral, 2010; Keck, 1991; Meneguello, 1989; Ribeiro, 2008; Secco, 2018). 
O surgimento do PS, em 1933, foi o resultado da aglutinação de pequenas organizações socialistas. A existência de diversos "núcleos fundadores" deixou sua marca e levou a uma história pontuada por cisões e reunificações ${ }^{5}$. A derrubada do governo Allende (PS) desencadeou uma diáspora: registros históricos mencionam cerca de vinte pequenos agrupamentos com existência orgânica (Tamayo, 2016), com destaque para a cisão de 1979 que deu origem ao "PS Almeyda" (Clodomiro Almeyda, ex-ministro de Allende) e ao "PS Altamirano" (Carlos Altamirano, senador pela Unidade Popular). Em 1989, os dois campos voltaram ao leito original e receberam a adesão de setores vinculadas à esquerda cristã, ao Partido Comunista e ao Movimiento de Izquierda Revolucionária (MIR) (Roberts, 1995).

Para os socialistas, a tarefa de retomar o partido após a ditadura se deu em uma situação distinta da dos frenteamplistas. Enquanto a FA pôde retomar uma trajetória interrompida ${ }^{6}$, o PS enfrentou uma profunda transformação. No período Allende o partido defendia uma estratégia classista em aliança com os comunistas e voltada para a construção de um "poder popular" alternativo à "democracia burguesa", posição posteriormente mantida pelo "PS Almeyda". Na retomada da democracia, no entanto, prevaleceram as posições do "PS Altamirano": aceitação incondicional da democracia representativa e defesa de uma aliança ampla e multiclassista para conduzir as reformas no país (Roberts, 1995).

Ademais, a relação do PS com sua base social se deu em condições distintas daquelas vivenciadas por PT e FA. As reformas neoliberais do período Pinochet alteraram a estrutura econômica e social do país, empoderaram os setores empresariais, e desarticularam e enfraqueceram os trabalhistas (Levitsky e Roberts, 2011). Ao mesmo tempo, temendo uma radicalização no processo de transição, a liderança do partido optou por desmobilizar suas bases e se concentrar nos canais institucionais (Roberts, 1995; Luna, 2016). Por fim, nas décadas seguintes à transição, as opções feitas pelo PS seguiriam a lógica de uma coalizão na qual a principal força, a democracia-cristã, situava-se ao centro, o que dificultou a delimitação de um perfil ideológico mais à esquerda e de um espaço próprio de atuação.

Como fica evidente, os momentos fundacionais do PT e da FA foram mais semelhantes. Os dois partidos surgiram e se firmaram como partidos desafiantes e, como tal, dispostos a colocar seus países de 
ponta-cabeça. Já o PS passou por uma refundação ao fim da ditadura pinochetista e voltou à condição de partido de governo no curso de uma profunda revisão ideológica e de uma drástica mudança na política de alianças. Petistas e frenteamplistas assumiram perfil ideologicamente difuso; mas, ancorados em ampla base social, traziam forte apelo à participação interna e à mobilização da sociedade. Já os socialistas optaram por desmobilizar o que lhes restava de base social e anunciar uma atuação centrada nas instituições. Mas enquanto a FA optou claramente por uma estrutura organizacional compatível com o funcionamento de uma ampla coalizão de forças, no PT prevaleceu uma ambiguidade organizacional, o que possibilitava a existência de partidos dentro do partido - muito embora seu núcleo fundante nunca tenha cogitado constituir uma "frente".

\section{AS BASES E A PARTICIPAÇÃO}

No PT e na FA o elogio à participação constituiu poderosa marca de fundação. No PS, não. Os petistas, desconfiados da democracia representativa, advogavam por uma "virada" participativa com início na organização dos trabalhadores pela base e desdobramento em um processo de transformação radical do país, o que correspondia ao ideário das Comunidades Eclesiais de Base (CEBs) e dos grupos de esquerda. O núcleo sindicalista não trazia uma formulação consistente sobre o tema, mas sua experiência prática levou-o a conclusões semelhantes. Como o Brasil seria reconstruído de baixo para cima, não fazia sentido pensar que no PT seria diferente. Na FA, as concepções dos setores de esquerda e dos sindicalistas eram semelhantes ao que se via no PT. Ademais, a organização de um movimento "frenteamplista" era imprescindível para sinalizar que ali se construía mais do que uma coalizão entre partidos e frações partidárias. Já no PS, as coisas eram vistas por outro ângulo: em vez de uma relação de domínio com o ambiente (Panebianco, 2005) - moldando a realidade conforme seus objetivos - aos socialistas se impôs um processo de adaptação, que implicou em adequar a política aos incentivos e restrições impostos pelo meio em que atuavam. Tal percepção teve profunda implicação na maneira como a participação dos filiados e militantes foi percebida.

Não obstante, os processos vivenciados pelo PT e pela FA mostram diferenças substanciais. No PT, os Núcleos de Base deveriam viabilizar uma dinâmica participativa. Mas já no III Encontro Nacional (EN), em 1984, discutia-se a "crise da nucleação" (Secco, 2018). O V EN, em 
1987 (PT, 1998:350), afirmou que "os núcleos estão abandonados". Três anos depois, o VII EN admitiu que "a maioria dos núcleos deixou de existir" (PT, 1998:443). E apesar do $1^{0}$ Congresso, em 1991, ter insistido no tema - "os núcleos são uma prioridade na política de organização do partido" (PT, 1998:521) - fato é que o projeto deu em nada.

Por um lado, prevaleceu uma subestimação do impacto da dinâmica eleitoral sobre o partido. Ainda que a Carta Eleitoral de 1982 afirmasse que as eleições eram "apenas um episódio [que] não pode desviar o partido de seus objetivos programáticos" (Partido dos Trabalhadores, 1998:131), logo se tornou comum a existência de núcleos efêmeros, mantidos apenas como locus de arregimentação para disputas internas e campanhas eleitorais (Secco, 2018). Por outro lado, a convergência na defesa das organizações de base possuía razões pragmáticas. Para o núcleo fundador, a promessa de participação funcionava como atrativo em um partido que dispunha de pouco tempo para recrutar milhares de filiados. Para a esquerda, tratava-se de terreno conhecido - acostumada às "tarefas de organização", os grupos podiam compensar a falta de base social com a expertise na luta por espaço na estrutura partidária. A convergência durou pouco tempo. Já no III EN a tendência majoritária derrotou as propostas da esquerda visando empoderar os núcleos (Secco, 2018). O estatuto de 2001 encerrou a discussão: as organizações de base passaram a ser instâncias consultivas, subordinadas aos Diretórios Municipais (DMs) e sem representação nos órgãos de decisão (Ribeiro, 2014).

Ainda que isso tenha limitado os espaços disponíveis aos filiados que desejassem fazer parte da vida interna do PT, a prevalência dos DMs como o único mecanismo de organização partidária no nível local não significou completa renúncia ao ethos participativo inicial. Samuels e Zucco (2014) estão certos ao argumentar que um diferencial do PT está em que os DMs são órgãos de existência real, e não instâncias cartoriais mobilizadas apenas nas eleições. Segundo os autores, o crescimento do petismo poderia ser explicado pela dinâmica organizativa a nível local, em uma estratégia que "can be summarized as 'mobilizing the organized'" (2014:4).

Persiste uma diferença, no entanto, entre "mobilizar os organizados" e conceder-lhes espaço nos processos decisórios. Até 2001, a chance de um filiado influenciar na constituição das instâncias superiores era nula: na medida em que se ascendia dos Encontros Municipais ao Nacional, mais 
claro ficava que participavam militantes vinculados a alguma força política. O quadro mudou parcialmente entre 2001 e 2013, com a introdução do Processo de Eleição Direta (PED) para as direções partidárias, bem como seus respectivos presidentes. Para além dos cálculos sobre quem perderia e quem ganharia, a mudança colocou em disputa concepções distintas de organização. Para a esquerda partidária, privilegiar a participação individualizada àquela que fluía pelas estruturas do partido contrariava o "espírito petista". A corrente majoritária, ancorada no discreto charme dos processos universais de escolha da democracia, argumentava que os Encontros privilegiavam os grupos organizados e não representavam o conjunto dos membros do PT (Amaral, 2013).

Na literatura internacional, Katz and Mair (1993 e 2002), referindo-se ao contexto europeu, sustentaram que a ampliação do sufrágio seria coerente com a ascensão do partido "na esfera pública". Ao diluir a força dos militantes e grupos organizados e empoderar um eleitorado supostamente menos ativo, desarticulado e moderado - os filiados -, a mudança ampliaria a autonomia dos líderes. Por outro lado, Scarrow, Webb e Farrel (2000) argumentaram se tratar de uma resposta à perda de legitimidade dos partidos, e que seria melhor "levar a revolução cognitiva a sério" em vez de supor um filiado passivo. No debate nacional, Ribeiro (2013), sustentou que o PED minou a articulação orgânica do partido, enfraqueceu instâncias e lideranças intermediárias, assim como os mecanismos de accountability que teriam seu locus principal nos Encontros. Amaral (2013:79), por sua vez, destacou o aumento na base de filiados como decorrência da adoção de uma forma de militância "mais inclusiva e mais aberta", reconhecendo, no entanto, a "menor intensidade" de tal participação, opinião também compartilhada por Ribeiro (2014:113).

De fato, o número de filiados passou de 420 mil em 2003 para pouco mais de 1,5 milhão em 2018, segundo dados do Tribunal Superior Eleitoral (TSE). Até 2013, a participação no PED se manteve alta, oscilando entre 38,0\% e 49,0\% daqueles aptos a votar, e atingiu seu pico em 2009, quando 518 mil petistas foram às urnas (Amaral, 2013; Melo e Nunes, 2015). O PED, no entanto, não resistiu à maior crise enfrentada pelo partido desde sua fundação. Após o impeachment de Dilma e a perda de $60 \%$ de suas 644 prefeituras nas eleições municipais de 2016, e sob intensa pressão interna, a Direção Nacional decidiu que no processo seriam eleitos apenas os DMs, seus presidentes e os delegados aos Encontros - que voltaram a eleger os órgãos dirigentes superiores. 
No novo PED, em 2017, participaram 290 mil votantes. Em 2019, com a recente recuperação partidária, a participação subiu para $351 \mathrm{mil}^{7}$. A crise afetou a malha organizativa. Em 2012 o PT estava organizado em 96,7\% dos municípios brasileiros (Ribeiro, 2013:252), mas em 2019 esse percentual havia caído para $62,0 \%{ }^{8}$.

Na FA a trajetória de participação das bases se deu no sentido oposto: os núcleos foram mantidos e aumentaram sua influência no processo decisório. A combinação entre representação dos setores políticos, membros de base e cidadãos/cidadãs independentes no Plenário Nacional (PN) - mas não em sua direção executiva - esteve presente desde a fundação, ainda que à época a participação da base fosse simbólica9 . Mas, a partir de 1986, os representantes dos comitês de base passaram a ocupar 33,9\% das vagas no PN, e após 1993 já tinham o mesmo peso que os setores políticos (Pedrabuena, 2012). A participação se estendeu à Executiva (Mesa Política), onde a representação de base atualmente ocupa o equivalente a $80 \%$ das vagas reservadas aos setores políticos.

Desde 1997 a FA realiza eleições internas para escolha dos órgãos dirigentes. Os filiados elegem o PN e os departamentais. Os filiados votam nos representantes dos setores políticos - em lista fechada - e nos delegados de base por meio de votação nominal. As assembleias dos comitês de base elegem diretamente participantes dos Congressos partidários. Após 2012, o presidente nacional e os presidentes departamentais passaram a ser eleitos em folha separada, sem vínculo com as listas dos setores (Pedrabuena, 2012).

Pesquisa tocada por Pérez, Piñeiro e Rosenblatt (2019) constata a existência de mais de 150 comitês ativos em Montevideo. Nas entrevistas realizadas para este artigo com dirigentes dos diversos setores, a participação da militância, ao lado do pluralismo vigente, foi apontada como um dos trunfos do partido:

[...] tu llegas a un pueblo de veinte casas que no tiene banco o estación de servicio, que solo hay un almacén y de repente vez ahí una casa tiene bandera del Frente Amplio y funciona el comité de base (Rafael Michelini).

Não obstante, dois pontos foram objeto de avaliações distintas. Agustín Canzani, coordenador da Fundação Liber Seregni, e o deputado Alejandro Sanchéz mostraram preocupação com a diminuição do número 
de membros ativos e a dificuldade de mobilização dos jovens. Em contrapartida, Verónica Piñeiro, eleita para a Mesa Política pela delegação de base por Montevidéu, argumentou que a participação se mantém em níveis compatíveis com a mobilização política na sociedade. Debate-se também a influência dos setores políticos nos comitês. De acordo com Verónica Piñeiro, a influência é matizada pelas discussões realizadas entre os representantes de base (reúnem-se em separado nas sessões do PN), e pelo processo de prestação de contas junto aos fóruns de origem - ainda que isto funcione melhor em Montevidéu. Já Alejandro Sanchéz e Enrique Rubio (Vertente Artiguista) veem a interferência dos setores nos comitês como um dos fatores que explica $\mathrm{o}$ arrefecimento na participação ${ }^{10}$. Seja qual for o motivo, o número de votantes nas eleições internas vem caindo: 227.795 em 2006; 170.770 em 2012 (Rosenblatt, Piñeiro e Pérez, 2016) e 94.183 em 2016 (segundo informação do site do partido).

O desenvolvimento organizacional da FA, ao contrário do PT, transcorreu sem grandes debates, ainda que tenham existido discordâncias em alguns pontos. Na introdução das eleições diretas para a presidência do partido, por exemplo, o requisito para ter direito a voto foi polêmico: a resolução aprovada permitia a adesão ao partido no momento da votação. Criticado por Verónica Piñeiro, o ponto foi responsável, segundo Enrique Rubio, pelo fato de que a resolução não foi aprovada por unanimidade, e sim por votação precedia por "dura negociação". Mas, ao contrário do que ocorreu no PT, não houve contraposição entre o primado da estrutura orgânica e o empoderamento dos filiados, uma vez que eles já elegiam diretamente as direções. Apenas não havia a eleição do presidente em separado. Ademais, o setor com maior penetração no eleitorado - o Movimiento de Participación Popular (MPP), situado à esquerda no partido - era também a principal força no que se refere à capacidade de mobilização da militância organizada.

No PS, após a redemocratização, a antiga estrutura baseada em núcleos foi substituída por outra, na qual as unidades básicas passaram a ser as comunais (Tamayo, 2016). O imediato esvaziamento das organizações de base se relevou compatível com a já mencionada estratégia adotada nos primeiros anos pós-ditadura. Segundo Luna e Rosenblatt (2012), no PS a base possui certa influência na vida local, mas não está representada na direção nacional. A relação entre os dois níveis carece de canais regulares, sendo acionada episodicamente nas disputas internas quando os diversos grupos definem suas estratégias, estabelecem 
alianças e lançam mão de seus quadros para mobilizar os militantes leais. A militância se aglutina em torno dos grupos, ciente de que "la dinámica faccional determina la participación al punto de que sería imposible intentar militar sin adscribir a corrientes" (Tamayo, 2016:13). Ao contrário do que ocorre na FA, não existe espaço de militância independente e nem mesmo os organismos territoriais se apresentam como locais privilegiados de participação - como ocorre nos DMs no PT -, substituídos por redes estabelecidas pelos grupos políticos.

O PS não é uma organização de jovens - em 2019, conforme o site do partido, apenas $8,1 \%$ dos filiados tinha menos de 30 anos. Não obstante, a dinâmica política da juventude chilena fez com que o partido investisse no setor. A Juventude Socialista (JS) possui autonomia orgânica, presença no Comitê Central (05 membros em 95) e em sua Comissão Política (01 em 07), assim como nas direções inferiores ${ }^{11}$. Mas também aí os setores políticos são o espaço básico de participação: é em torno deles que se verifica um mínimo de funcionamento orgânico, de forma que a trajetória daqueles socializados após a ditadura tem início nas "franjas" de um setor e se desenvolve até que as relações se transformem em adesão plena (Tamayo, 2016).

Desde a redemocratização, ao contrário do transcorrido no PT e na FA, as regras que regulam a dinâmica eleitoral interna não passaram por modificações sensíveis. Os órgãos dirigentes são eleitos a cada dois anos. Todo filiado, com no mínimo seis meses de filiação e em dia com a contribuição financeira, tem direito a voto, podendo escolher uma das listas ou marcar um nome em seu interior ${ }^{12}$. Os candidatos à presidência encabeçam as listas para o Comitê Central, que por maioria absoluta elege o Presidente e o Secretário Geral. A eleição utiliza um sistema proporcional com cifra repartidora. Entre 2006 e 2017 o comparecimento médio esteve próximo de 30 mil. Em 2019, com 75\% das urnas apuradas, o site do partido informava a participação de 38.099 filiados, um número expressivo quando se leva em conta o total de membros - cerca de 130 mil no mesmo ano.

Neste artigo, argumenta-se que um dos fatores com impacto sobre a autonomia das lideranças é a influência das bases sobre o processo decisório. Quanto a isso, salta aos olhos a diferença entre a FA e os demais. Muito provavelmente a experiência da Frente Ampla seja única na América Latina e até mesmo no mundo. Trata-se de um partido onde filiados e militantes possuem voz e espaço qualificado para intervir; 
de uma organização que se distingue pelo grau de responsividade à sua base social sem que isso impacte negativamente sua capacidade de atuação. E ainda que os dados aqui mobilizados se refiram aos membros do partido, o raciocínio pode ser estendido aos apoiadores externos.

Daí não se conclui que PT e PS estejam no mesmo nível. Nesse ponto é possível discordar de Handlin e Collier (2011) e Levitsky e Roberts (2011), para quem petistas e socialistas estariam igualmente afastados dos uruguaios no que se refere à sua base de massa. A dinâmica interna do PT se mostra mais participativa, ainda que seus membros de base não tenham influência direta sobre as decisões. A relação com suas bases sociais não foi afetada por um processo de reformas tão radical quanto o chileno. Da fundação até a conquista do governo federal, os petistas delimitaram um espaço próprio de atuação, evitaram coligações com os partidos do status quo e conseguiram estabelecer um eixo diferenciado para a competição política, o que possibilitou ao partido manter índices de identificação superiores a $20 \%$ junto ao eleitorado. Nada disso foi possível ao PS, sócio minoritário na Concertación, que viu seu nível de identificação com o eleitorado chileno descer a taxas inexpressivas. Estudo realizado por Amaral (2011) mostra que o PT continuava conectado à sociedade civil ao final do primeiro governo Lula. Ribeiro (2014), por sua vez, reconhece que o partido se mantém como uma espécie "anfíbia", capaz de nadar nas águas da sociedade civil apesar da intensa vivência institucional. De fato, não fosse assim, o PT não teria conseguido colocar cerca de um milhão de pessoas nas ruas contra o impeachment de Dilma Rousseff, em dezembro de 2015. Já o PS, há muito desapareceu das ruas chilenas.

\section{O BALANÇO DO PODER INTERNO: PLURALISMO, DISTÂNCIA IDEOLÓGICA E LIDERANÇA}

A literatura registra uma ampla discussão sobre a dinâmica interna dos partidos políticos, prevalecendo, dentre as classificações disponíveis, as que se baseiam em critérios organizativos. Rose (1976) distinguiu entre grupos dotados de maior organicidade (as facções), e de existência mais informal e flexível (as tendências), distinção aceita por Panebianco (2005). Sartori (2005:110) utiliza o termo facção para designar qualquer agrupamento no interior de um partido e aponta as facções como "grupos específicos de poder" dotados de alta visibilidade, enquanto as tendências são caraterizadas como "um conjunto estabelecido de atitudes" que expressam diferenciações pouco destacadas. O autor 
leva em conta, ainda, a motivação, diferenciando os grupos voltados exclusivamente para a disputa de poder e os benefícios daí advindos, daqueles que funcionariam também como "grupos de promoção", preocupados com a difusão de ideias.

Os principais setores políticos da FA caracterizam-se como facções, e o partido é o mais fracionado dentre os aqui estudados. Analisado longitudinalmente, seu quadro interno apresenta grande variação, com saída e entrada de grupos, processos de racha e fusão e oscilação no peso relativo dos diversos setores. Apenas socialistas e comunistas mantiveram presença desde 1971. Atualmente o site do partido registra 30 "setores políticos" com representação no PN: 10 haviam conseguido representação na Câmara dos Deputados e 06 elegeram ao menos um senador em 2014. A fracionalização tem aumentado, e nas eleições de 2016 para o PN o número efetivo de facções chegou a $8,8^{13}$.

Trajetórias e identidades prévias mantém enorme relevância e se refletem no alto grau de institucionalização das principais facções, o que não impediu que a Frente deixasse de ser uma coalizão de partidos e se transformasse em um partido propriamente dito (Lanzaro 2004). Segundo Yafeé (2013:74), “los partidos y grupos constituyentes de la coalición fundadora terminaron convirtiéndose en fracciones de un nuevo partido que los reunió sin fundirlos".

Nas entrevistas realizadas para este artigo, o ponto foi objeto de apreciações variadas. Enquanto Marcelo Reboledo afirmava crer "firmemente que [a FA] es uma coalición de partidos", Verónica Piñeiro sustentava taxativamente que a Frente "es um partido". Para Eduardo Lorier (Partido Comunista), "a via uruguaya para el socialismo passa por el Frente Amplio". Segundo Mónica Xavier (Partido Socialista), "nadie pretende la eliminación de las identidades própias", mas a síntese das diferentes trajetórias que hoje seria a FA poderia "en algún momento terminar en un único partido con diferentes vertientes" 14 . Para Rafael Michelini, a FA "es un partido táctico que como se reinventa permanentemente termina convirtiéndose en un partido estratégico, pero no por definición". Neste artigo segue-se a sugestão de Sartori (2005): a escolha das facções como nível de análise só se justifica quando elas mantêm uma relação de quase soberania para com o partido, o que não é o caso na FA. 
Para além de grupos que se articulam em torno da disputa pelo poder, as principais facções da FA se distinguem por expressar ideias e concepções, o que torna possível distribuí-las em um contínuo esquerda / direta (Altman, 2002; Rosenblatt, Piñeiro e Pérez, 2016). A Frente Liber Seregni (FLS) agrega facções mais moderadas - Nuevo Espacio (NE), Alianza Progresista (AP) e Asamblea Uruguai (AU). Do outro lado, Movimiento de Participación Popular (MPP), Partido Comunista do Uruguai (PCU), Compromisso Frenteamplista (CF) e, mais recentemente, Casa Grande, situam-se à esquerda. Entre os dois blocos é possível plotar o Partido Socialista (PS).

Analisando o desempenho das facções nas eleições para o Senado entre 1971 e 2009, Yafeé (2013:80) mostra que:

[...] las posiciones relativas de las fracciones varían una y otra vez. Sólo dos alcanzaron el primer lugar en más de una ocasión: el PCU en 1971 y en 1989, y el MPP en 2004 y 2009. Hasta 2004 ningún sector había logrado tener la mayoría simple por dos periodos consecutivos y ninguna fracción alcanzó nunca la mayoría absoluta de los votos del FA.

É notável o desempenho dos setores à esquerda. No período mencionado acima, apenas em 1994 e 1999 facções "à direita" - AU e PS - lideraram a votação para o Senado. Na eleição de 2014, o MPP foi o setor mais votado para o Senado (06 das 16 cadeiras conquistadas) e para a Câmara dos Deputados ( 23 em 50 cadeiras) (Rosenblatt, Piñeiro e Pérez, 2016). Desde 2004 o MPP se mantém como a maior minoria no partido, condição que se repete nas eleições para o Plenário Nacional desde 2006 (Chasquetti, 2007; Ponte, 2013, Rosenblatt, Piñeiro y Verónica, 2016).

Não obstante, observa-se um relativo equilíbrio entre os campos, em especial se considerados outros momentos da disputa interna. Nas primárias para as eleições presidenciais de 2009, José Mujica (MPP) derrotou Danilo Astori (AU) - apoiado por Tabaré, socialistas e FLS por $52 \%$ a 40\% dos votos (Garcé, 2010). Em 2013 Tabaré foi escolhido e a esquerda indicou Raul Sendic (CF) como vice-presidente (Garce, 2013). Nas primárias de 2019, Daniel Martinez (PS) superou Carolina Cosse (MPP) e Oscar Andrade (PC) para sagrar-se candidato à Presidência da República ${ }^{15}$. Nas ocasiões em que o presidente do partido foi eleito em folha separada - eleição pela regra da pluralidade -, foi vitoriosa uma aliança entre os socialistas e a FLS. Em 2012, Mónica Xavier foi 
eleita com 43\% dos votos. Em 2016 foi a vez de Javier Miranda, com $37,5 \%$. Ambos derrotaram candidatos do MPP, do PCU e da VA (Ponte, 2013; Rosenblatt, Piñeiro y Verónica, 2016). Por fim, cabe mencionar a alternância na prefeitura de Montevidéu. Desde 1989 socialistas, comunistas e lideranças vinculadas ao MPP e à VA, estiveram à frente da municipalidade. Em 2015 Daniel Martinez (PS) foi eleito prefeito obtendo, na lista da FA, o dobro de votos de Lucia Topolansky (MPP) ${ }^{16}$.

O peso da esquerda deve ser avaliado à luz de outros fatores. O primeiro remete à convicção de que a força da Frente se baseia em sua capacidade de promover uma "síntese" de seus diversos setores. Além disso, como lembram Rosenblatt, Piñeiro e Pérez (2016), "estos alineamientos suelen romperse ya que los diferentes sectores adoptan posiciones políticas diversas". Os alinhamentos seriam consistentes na política econômica (posições menos expansivas em termos de gastos públicos versus visões mais desenvolvimentistas) e na política internacional (posições assumidas nos casos de Venezuela e Nicarágua ${ }^{17}$ ), mas se modificam em questões como segurança cidadã, meio ambiente, violações de direitos na ditadura e a nova agenda de direitos.

Na FA uma coalizão dominante dividida garante a estabilidade organizacional por meio de uma dinâmica consociativa. A presença de grupos distintos, sem que nenhum se impusesse de forma definitiva, manteve-se como traço marcante do partido e refletiu, ainda que de forma diferenciada, em todos os seus governos (Chasquetti, 2007; Moraes, Guedes e Luján, 2012; Chasquetti, Buquet e Cardarello, 2013; Pérez e Piñeiro, 2016). Em um arranjo com tais características não apenas a efetividade, mas também a inclusividade das regras é crucial. As mudanças realizadas desde sua fundação sempre tornaram o arranjo mais inclusivo (Pedrabuena, 2012): empoderamento dos comitês de base; adoção de eleição direta para as direções e, posteriormente, para os presidentes; definição das candidaturas à presidência da República e à Prefeitura de Montevidéu no Congresso do partido ou em primárias; e aumento no número de assuntos a exigir maiorias qualificadas no $\mathrm{PN}^{18}$. Ao mesmo tempo, reforçando o caráter partidário da FA, o cumprimento das decisões se tornou obrigatório, salvo em caso de expressa liberação.

A análise do PS chileno revela um quadro diferenciado. De acordo com Gamboa e Salcedo (2009), seus principais grupos internos poderiam ser caracterizados como faç̧ões por serem: estáveis, reconhecidos pelo partido, dotados de alguma organização interna e capazes de atuar 
coordenadamente para atingir seus objetivos. Mas em um contínuo subpartidário, tais grupos estariam mais próximos de tendências do que de facções. A diferença está no grau de organicidade. No PS os grupos compartilham as características apontadas por Panebianco (2005:75-76) para as tendências: "agregações de vértice, desprovidas de bases organizacionais ao longo do corpo do partido". Seus vínculos internos são frágeis e fluidos. O menor grau de institucionalização da vida partidária irá se refletir em uma dinâmica marcada por "lógicas y códigos de características consuetudinarias y no contenidas en la normativa partidista" (Tamayo, 2016:10). Ademais, as divisões são menos destacadas e visíveis - nenhum grupo possui estrutura orgânica, mecanismos de adesão formal, sede ou mesmo site na internet -, ao contrário do que ocorre na FA.

A fracionalização, bem menor que na FA, esteve inicialmente vinculada à trajetória dos "cuatro o cinco grupos internos principales [que] han dado vida a la orgánica partidaria desde 1990 en adelante" (Gamboa e Salcedo, 2009:678). Do "PS Almeyda" surgiram Nueva Izquierda e Tercerismo - um mais crítico à condução política e econômica dos primeiros anos e outro mais preocupado em buscar acordos em prol da governabilidade. Do "PS Altamirano" vieram os Renovados de Arrate (referência a Jorge Arrate), próximos às tradições do socialismo chileno, e os Renovados de Núñez (referência a Ricardo Núñez), influenciados pela social-democracia europeia. Em meados dos anos 1990 uma dissidência da Nueva Izquierda deu origem ao Colectivo de Identidad Socialista, e as forças do "arratismo" e do "nuñismo" se uniram na Renovação Socialista, também conhecida como Megatendência (Tamayo, 2016). Em 2006 constituiu-se o Grandes Alamedas - um heterogêneo campo político com objetivo de se contrapor a Nueva Izquierda. Em 2015, a partir das mobilizações estudantis, surgiu a Izquierda Socialista, buscando "una reconstrucción del partido como una fuerza crítica y transformadora"19. Ao que indicam depoimentos colhidos para este artigo, apenas Nueva Izquierda e Tercerismo contariam com maior grau de organização nos dias de hoje $\mathrm{e}^{20}$.

A evolução do quadro interno ao PS denota um indiscutível processo de convergência. Diferenças ideológicas e programáticas, marcantes no início dos anos 1990, deixaram de fazer sentido. Entrevistas realizadas entre 2012 e 2015 por Tamayo (2016), com lideranças dos principais grupos, revelam total acordo quanto ao ponto: 
hoy día (los grupos) tienen que ver con las lealtades que se construyeron previamente y en torno a las personas que siguen siendo activas en el PS (...). pero me costaría mucho poder explicártelo en función de la realidad política actual. Yo creo que la política y lo programático dejaron de pesar hace mucho tiempo (Jaime Pérez de Arce apud Tamayo, 2016:12).

Tal percepção é compartilhada por praticamente toda a literatura (Gamboa e Salcedo, 2009; Luna e Rosenblatt, 2012). As tendências do PS atuam como grupos de interesse em um sistema voltado para organizar a disputa por cargos. Nas eleições internas fazem valer vínculos de lealdade, caudilhismos locais e mecanismos de patronagem, mobilizando sua militância e estabelecendo alianças para definir sua posição na estrutura partidária. Tamayo (2016) observa que lideranças socializadas no século XX usam a palavra "lotes" para se referir às tendências, manifestando certo mal-estar ou percepção de perda de horizonte político. Por outro lado, militantes socializados após os anos 2000 usam o termo de forma corriqueira e sem conotação negativa, na medida em que ele expressa um elemento primordial para a organização da vida partidária.

O elevado consenso ideológico/programático entre as principais tendências facilita a conformação de um padrão moderado à dinâmica interna, o que permite enorme flexibilidade no processo de formação de coalizões e torna inexistentes os grupos de veto. Além disso, uma análise dos processos eleitorais desde os anos 1990 descortina um contexto em que nenhum setor é capaz de se impor, e o desfecho da luta política depende das estratégias coalizacionais desenvolvidas pelas principais correntes.

Dados disponibilizados por Gamboa e Salcedo (2009), acessíveis no site do partido, permitem clarear o ponto. Ainda que os setores Renovados tenham se saído melhor na transição para a democracia (Roberts, 1995), sua influência refluiu a partir dos primeiros anos. Em seu lugar, adquiriram maior proeminência Tercerismo e Nueva Izquierda. Esta última, exceção feita ao biênio 2005/2006, ocupou a presidência do partido entre 2000 e 2015 - ainda que sempre na condição de maior minoria e sustentada por coalizões diferenciadas (Gamboa e Salcedo, 2009). O Tercerismo, por sua vez, esteve presente em todas as coalizões vencedoras nas eleições para o Comitê Central entre 1992 e 2008, retomando esta condição a partir de 2015. A criação do Grandes Alamedas deslocou a Nueva Izquierda da presidência do partido em 2015 e, com 
o apoio do Tercerismo e do Colectivo, elegeu a senadora Isabel Allende como primeira presidenta do partido. Não obstante, em 2017 as quatro tendências compuseram a chapa Unidad Socialista, que obteve $76 \%$ dos votos na eleição para o Comitê Central. Em 2019 a coalizão pela "unidade" se impôs novamente ${ }^{21}$.

O PT apresenta uma dinâmica interna ainda mais fluida que o PS. Seus grupos internos possuem baixa organicidade e atuam como "articulações de vértice" que precariamente delimitam posições no interior do partido. Dada a dimensão do país e sua organização federativa, são muitos os grupos locais ou regionais. A maioria deles não resistiu ao tempo, de forma que o mapa das tendências passou por constantes alterações. Desde sua fundação, apenas três grupos se mantêm: Democracia Socialista (DS) e O Trabalho, situados à esquerda, e a Articulação $0^{22}$. Além disso, observa-se um emaranhado de rachas, fusões e conformação de "campos políticos" de existência efêmera.

O que certamente distingue o PT dos demais casos é a existência de uma estratégia política traçada a partir do núcleo paulista, que visa garantir a centralização e unidade de ação do partido. Iniciado em 1983, com o surgimento da Articulação, o movimento teve seu desfecho no I Congresso, em 1991. No curso da década, a Articulação, com maioria absoluta dos votos nos Encontros realizados, venceu sua batalha contra os grupos de esquerda (PT, 1998; Lacerda, 2002). O sucesso pode ser creditado ao prestígio de suas principais lideranças junto às bases, Lula em especial, e à defesa da importância estratégica do partido contra o "vanguardismo" de organizações que o tratavam como instrumento tático e transitório na luta pelo socialismo. Nesse processo a Articulação se consolidou como tendência, ainda que inicialmente não se visse como tal, a deixar implícito que falava pelo todo do PT e não como parte dele.

A regulamentação do direito de tendências e a aplicação do princípio da proporcionalidade eram os pontos em discussão. A proporcionalidade, com uma barreira de 10\%, era adotada na composição dos órgãos de direção. No entanto, a regra não era aplicada para as Comissões Executivas, o que garantia à corrente majoritária o controle dos postos chave no partido. Resolução aprovada no V EN, em 1987, evidencia a vinculação entre os pontos: 
enquanto perdurar o fenômeno das tendências com as características que marcam a maioria das tendências hoje presentes no PT, (...) devemos reservar à maioria as funções na Comissão Executiva Nacional (PT, 1998:359).

Em 1990 o VII Encontro aprovou o afastamento das "organizações políticas autônomas que são outros partidos que não o PT" (PT, 1998: 447) e decidiu permitir a participação proporcional nas Executivas das chapas que alcançassem 10\% de votação. O I Congresso (1991) derrubou a barreira dos 10\% para os Diretórios e obrigou todas as organizações a aceitar o "caráter estratégico" do PT, diluindo-se organicamente, sob pena de expulsão (Ribeiro, 2008; Secco, 2018). Por não se submeterem às novas regras, Causa Operária e Convergência Socialista foram expulsas do partido ${ }^{23}$.

Não obstante ter vencido a batalha contra as organizações de esquerda, na década de 1990 a Articulação perdeu seu status de corrente majoritária e passou a depender de coalizões com grupos de perfil moderado para manter a direção do partido. A crise do socialismo e as tensões entre a presença institucional e a atuação do partido nos movimentos sociais escancararam a heterogeneidade ideológica no interior da tendência. Em 1993, no VIII EN, a esquerda atingiu sua maior votação na história do PT (55,6\%), e a Articulação foi derrotada por uma coalizão comandada pela dissidente Articulação de Esquerda. O controle do partido foi retomado no Encontro seguinte, em 1995, com a eleição de José Dirceu para a presidência. Dirceu foi reeleito em 1997, 1999 e no primeiro PED, em 2001. À frente de uma aliança entre a Articulação e grupos menores - o Campo Majoritário - comandou o processo de centralização do partido e preparou o terreno para a mudança na política de alianças que resultaria na chapa presidencial de 2002 (Amaral, 2010; Ribeiro, 2008).

Para Ribeiro (2014:113), a primeira eleição realizada sob o PED teria "consolidated the dominion of a bureaucratic mini-oligarchy over the PT's apparatus". Mas a análise dos resultados permite dizer que, enquanto vigorou de forma plena, o PED não teve, por si mesmo, um efeito de grande magnitude nas disputas internas. É verdade que a partir de então o campo majoritário elegeu todos os presidentes do partido, mas sua vitória em 2001, no primeiro PED, foi obtida com base em percentual de votos $(55,6 \%)$ semelhante àqueles registrados nos Encontros de 1995, 1997 e 1999 (54\%; 52,6\% e 54,8\%). 
Em 2005, agora com a denominação de Construindo um Novo Brasil (CNB) e sob o impacto do "mensalão", a votação do setor majoritário caiu para $42,8 \%$ : a presidência foi mantida, em segundo turno, com uma vantagem de $3,2 \%$ sobre o candidato da esquerda. Nos PEDs de 2007, 2009 e 2013, o CNB venceu a disputa com média de votos superior a 60\% (Amaral, 2010; Melo e Nunes, 2015), mas nesses casos é necessário levar em conta o efeito da reeleição de Lula e seu desempenho no governo. Ao fim e ao cabo, Amaral (2010) parece ter razão ao sustentar que a mudança nas regras teria tornado o processo sucessório petista mais conectado aos humores da conjuntura política nacional.

O PT é um partido conduzido por uma coalizão dominante coesa e estável. Ao longo de sua trajetória, o controle sobre a maior parte, quando não a totalidade de seus postos chave, esteve nas mãos de um mesmo grupo - isso vale também para as pastas ministeriais. Como toda coalizão dominante, a Articulação sempre foi "uma construção potencialmente precária" (Panebianco, 2005:74), mas seu núcleo duro sobreviveu a rachas expressivos e situações de crise aguda. Sua "volta por cima", após a derrota sofrida em 1993, foi facilitada por três fatores: a) o incremento dos recursos disponíveis após 1995, quando o financiamento proveniente do Fundo Partidário passou a ser significativo, e em especial após 2002, com a vitória na Presidência da República; b) o sucesso do período Lula, que fez com que o debate passasse a priorizar a dimensão institucional da luta política e as questões de governo; e, paralelamente, c) um movimento em direção ao centro feito pela DS e por setores que haviam se vinculado à Articulação de Esquerda, o que propiciou uma diminuição na distância ideológica e programática entre as principais tendências - em especial no que se refere à relação com a institucionalidade, à política econômica e à política de alianças (Lacerda, 2002; Amaral 2010). Em consequência, entre 2007 e 2013, candidatos situados do centro para a direita no espectro partidário obtiveram, em média, $84,3 \%$ dos votos na eleição para Presidência do partido, isolando as alternativas apresentadas pelos setores que se mantiveram à esquerda ${ }^{24}$. A negociação entre setores próximos, ao invés do enfrentamento direto entre campos distantes, passou a ser regra, e facilitou a estratégia do CNB.

Nem mesmo a crise aberta após 2014 fez com que o controle do partido mudasse de mãos. No VI Congresso, em 2017, o movimento "Muda PT" - convergência entre grupos moderados, setores da esquerda e lideranças independentes - lançou a candidatura do então senador 
Lindberg Farias à presidência, visando "renovar a direção do partido". A eleição foi vencida pela ex-senadora Gleisi Hoffman (CNB), com $61,9 \%$ dos votos ${ }^{25}$, num evento que escancarou o deserto argumentativo que tomou conta da dinâmica interna do partido. A estratégia traçada pelo CNB - centrada na denúncia do impeachment de Dilma como um golpe e na consigna "Fora Temer" - permitiu reorganizar parcela da base partidária, mas bloqueou por completo qualquer discussão sobre os erros que levaram à crise. Tal como na década de 1980, tratava-se de defender o PT. O alvo agora não eram os "partidos dentro do partido", mas os "golpistas" - ainda que parte deles continuasse a ser aceito em alianças eleitorais nos estados e municípios.

\section{Lideranças, competência e hegemonia}

Resta analisar, no que tange aos jogos horizontais, a existência ou não de uma única liderança reconhecida como a melhor expressão pública do partido e dotada de legitimidade suficiente para servir como ponto de aglutinação interna. Diferente do líder carismático, que busca construir um partido à sua imagem e semelhança, aqui interessa o líder dotado de competência: um "recurso fundamental do poder organizativo [...] um saber especializado que decorre da experiência no manejo das relações político-organizativas internas e externas ao partido [e] da ideia de que aquele agente específico é indispensável na função que ocupa" (Panebianco, 2005:66).

A existência de uma única liderança com tais características favorece a conformação de um quadro de hegemonia. O líder funciona como uma espécie de argamassa, contribuindo para dar coesão à coalizão dominante que assim se constrói a partir do "círculo" mais próximo a ele. Já a existência de mais de uma referência pública facilita a conformação de um ambiente pluralista. O PT ilustra a primeira situação. PS e FA, a segunda.

Até meados dos anos 1990, a FA se manteve unida em torno de uma única e consensual referência. Candidato à Presidência da República em 1971, sem vínculo com qualquer facção, o general Liber Seregni viu seu prestígio se ampliar ao longo de quase dez anos de cárcere, para depois consolidar-se graças a seu papel na transição para a democracia e nos anos seguintes (Lanzaro, 2001). Seregni foi candidato à Presidência da República em 1989 e presidiu o partido até renunciar em 1996. 
A renúncia se deu em meio à ascensão de Tabaré Vázquez e coincide com o processo de renovação programática no interior da FA (Luna, 2007; Yafeé, 2005, 2013). A perspectiva de uma vitória nas eleições para a Presidência, a condução "moderada" (Lanzaro, 2001) do governo de Montevidéu e a debacle do socialismo real enfraquecendo (momentaneamente) a esquerda partidária, contribuíram para a construção de uma coalizão interna, cujo objetivo era facilitar a disputa do eleitorado situado ao centro. Enquanto Tabaré proclamava a necessidade de uma "atualização" programática, Liber Seregni defendia Danilo Astori (companheiro de chapa em 1989 e liderança independente que depois criaria sua própria facção - a Asamblea Uruguay) como representante da FA "fundacional". A vitória de Tabaré foi alicerçada pelo sucesso da gestão à frente da capital, e se consolidou com base em duas decisões da FA: a) a de aprovar, em 1994, a aliança eleitoral firmada para as eleições presidenciais com o PDC e setores egressos do Partido Nacional - o Encontro Progressista; e b) a de rechaçar o acordo firmado entre Seregni e dirigentes dos partidos tradicionais, em torno das reformas constitucionais de 1996. Após a renúncia de Seregni, Tabaré foi eleito presidente do partido por unanimidade; e em 1998 derrotou Astori nas primárias para a eleição presidencial de 1999 apoiado por $82 \%$ dos votos.

A disputa entre Tabaré e Astori contribuiu para que o dissenso fosse reconhecido e institucionalizado (Yafeé, 2005): até então, a competição pela liderança era vista como ameaça à unidade e disciplina partidárias. $\mathrm{O}$ fato de Tabaré ter trilhado uma trajetória não dependente do aparato - mantinha uma relação apenas "discreta" (Lanzaro, 2001) com sua facção, o Partido Socialista - contribuiu para que ele se tornasse, tal como Seregni, uma liderança com amplo trânsito e capaz de operar com relativa autonomia face à disputa interna. Isso não impediu a derrota na definição da candidatura presidencial para 2009, quando José "Pepe" Mujica venceu as primárias sobre Astori - apoiado por Tabaré -, com 52\% dos votos.

O PS, desde a redemocratização, registra alternância entre suas lideranças. À diferença da FA, a disputa se realizaria entre líderes das diversas tendências, não se registrando situações ou períodos nos quais uma única liderança fosse capaz de se apresentar como uma expressão consensual do partido. 
Clodomiro Almeyda e Carlos Altamirano se retiraram da política tão logo retornaram ao Chile ${ }^{26}$. Inicialmente o protagonismo esteve nas mãos daqueles vinculados a Altamirano na disputa pela "renovação": Ricardo Lagos, Ricardo Núnez Muñoz e Jorge Arrate. Figura chave no plebiscito de 1988 e principal referência pública no campo socialista, Lagos foi um dos fundadores do Partido por la Democracia (PPD) - criado para contornar a proibição de que partidos de extração marxista participassem do processo legal - legenda à qual se manteria vinculado (Roberts, 1995). Núnez, responsável pela rearticulação do "PS-Altamirano" ao final da ditadura (Roberts, 1995), desvinculou-se do PPD para retornar ao PS em 1991, partido que presidiu nos períodos de 1991-1992, 1998-2000 e 2005-2006, e pelo qual ocupou uma cadeira no Senado por três legislaturas. Arrate presidiu o partido em 1990 e participou dos dois primeiros governos da Concertación, mas se afastou do PS e disputou a Presidência da República em 2009 pelo Partido Comunista (Quiroga, 2012). Oriundo do "PS-Almeyda", coube a Camilo Escalona travar a disputa. Com trajetória constituída na clandestinidade, o dirigente era desconhecido do público, mas se aproveitou da maior inserção de seu grupo na máquina partidária para organizar a mais consistente das tendências do socialismo, a Nueva Izquierda. Isso lhe possibilitou tornar-se a liderança com mais tempo na presidência do PS (1994-1998; 2000-2003 e 2006-2010), ser eleito deputado e, posteriormente, ocupar uma cadeira no Senado entre 2006 e 2014 (Roberts, 1995; Biblioteca Nacional del Congreso de Chile).

Um processo de renovação teve início a partir de meados dos anos 2000, com Izabel Allende Bussi (Grandes Alamedas) e Michelle Bachelet. Deputada entre 1998 e 2010, e a partir de então senadora, Izabel foi a primeira mulher a presidir o Senado e, posteriormente, o PS. Bachelet inaugurou a alternância de gênero na Presidência da República e se tornou a principal referência socialista no país, ainda que não fosse uma liderança partidária stricto sensu. Sem nunca ter pertencido à elite do PS, sua atuação, nos dois governos e posteriormente a eles, mostrou pouca relação com a dinâmica interna do partido. Em 2017, Álvaro Elizalde (Tercerismo) foi eleito presidente do partido, sendo reconduzido em 2019 no contexto da já referida "unidade" entre os maiores grupos políticos.

No PT nunca houve contestação à competência de Lula. Sua figura sempre esteve acima da luta interna, representando um ponto de unidade e equilíbrio; e após 1989 foi se tornando uma referência cada vez maior 
do que o partido perante o eleitorado. A análise de sua trajetória levou a formulações distintas na literatura. Samuels e Shugart (2010) a veem como um indicativo de afastamento em relação ao PT e apontam a exigência de autonomia feita para a campanha presidencial de 2008, bem como as políticas praticadas no primeiro governo, como evidências nesse sentido. Esquecem-se, no entanto, que nada disso era estranho à estratégia definida pela corrente majoritária no partido, à qual Lula sempre esteve vinculado. Mesmo a reforma da Previdência de 2003, que provocou tensões e um racha no partido, foi apoiada pela grande maioria dos petistas.

Na opinião de Singer (2012:15), seria possível falar de um novo fenômeno, o lulismo, fruto do encontro de Lula com o "subproletariado" por meio de um programa que mesclava ortodoxia econômica e redistribuição de renda. Tal encontro teria provocado um realinhamento do eleitorado, separando politicamente ricos e pobres a partir de 2006. Mas, se é verdade que a partir de 2002 a diferença entre eleitores do PT e de Lula foi se tornando mais evidente (Rennó e Cabello, 2010; Terron e Soares e Terron, 2010), e que políticas como o Bolsa Família permitiram adicionar estratos sociais marginalizados à base original do PT (Hunter e Power, 2008), daí não se pode deduzir que o lulismo represente um realinhamento eleitoral estável ou que denote um descolamento em relação ao petismo. Pelo contrário, evidências empíricas indicam que quanto mais um eleitor gosta de Lula, maior a chance de gostar do PT, e vice-versa (Rennó e Cabello, 2010). Lulistas e petistas são diferentes, mas não representam conjuntos que apenas se tangenciam. Todo petista tem em Lula uma referência; trata-se de um subconjunto menor e mais bem definido no interior de um conjunto maior e mais difuso.

É indiscutível que o sucesso do PT tem muito a ver com Lula. O que a literatura deixou de lado foi a análise das consequências de sua afirmação como única liderança capaz de conduzir o partido. Tal situação não encontra similar nos demais partidos e foi decisiva para a consolidação do um grupo hegemônico na direção partidária. Vencida a segunda eleição presidencial, Lula se tornou um "deus". Se em 2006, o ex-senador Eduardo Suplicy conseguiu forçar uma primária para a escolha do candidato à Presidência da República, em 2009 Lula impôs a candidatura de Dilma Rousseff à sua sucessão e sufocou qualquer articulação em contrário. Posteriormente o quadro se manteve; e mesmo 
no período em que esteve preso, apoiado em seu círculo mais próximo Lula continuou determinando de forma incontestável os caminhos do partido.

Ao analisar os jogos horizontais nos três partidos, esta seção permitiu reforçar o destaque concedido à FA. Pode-se argumentar que também entre os socialistas chilenos prevaleceu uma dinâmica consociativa em um cenário onde nenhuma liderança logrou se colocar acima das demais. Mas a diferença é enorme. Na FA, os acordos não se realizavam apenas entre os setores políticos, dada a impossibilidade de se descartar a representação das bases. Além disso, o consociativismo uruguaio operava em um contexto mais complexo, de forte diversidade ideológica, ao contrário do quadro encontrado no PS, onde os setores à esquerda não influenciam as decisões do partido. Do outro lado, ressalva feita a um curto período, a hegemonia da corrente majoritária no PT nunca foi ameaçada. O que se apresentava como uma possibilidade nos primeiros anos, consolidou-se com a sequência de eventos - em especial após a conquista da Presidência da República, com o fortalecimento da liderança de Lula, a acentuada acomodação programática, e a saída dos setores à esquerda que formaram o PSOL.

\section{CONCLUSÃO}

Este artigo comparou o grau de autonomia adquirido pelas lideranças da Frente Ampla (FA), Partido dos Trabalhadoes (PT) e Partido Socialista (PS). Como em qualquer relação de representação, líderes necessitam autonomia na condução de seus partidos. O problema aparece quando o que deveria ser uma relação de delegação, com autorização e controle, se transforma em abdicação.

O argumento central é de que a discricionariedade dos líderes na tomada de decisões depende: a) da influência das bases no processo decisório; b) do balanço de poder entre os diversos grupos no interior de cada partido; c) da distância ideológica/programática entre tais grupos; e d) da existência de uma única liderança incontestavelmente reconhecida como capaz de servir como ponto de referência e aglutinação do partido.

Não se argumenta aqui a favor de uma relação de causalidade stricto sensu entre cada um dos fatores analisados e a autonomia das lideranças. O que se pode afirmar é que a depender de como eles se combi- 
nem serão obtidos resultados diferentes. Os quatro fatores interagem. Em situações de pluralismo interno, as bases adquirem mais opções na relação com os líderes. Mas as opções oferecidas pelo pluralismo podem se restringir se os diversos grupos tiverem pontos ideais muito próximos - uma situação que tende a favorecer os acordos "por cima". Por fim, o poder exercido por uma liderança inconteste pode tornar ainda mais hegemônica a atuação da facção ou tendência que esteja no controle das zonas de incerteza do partido.

O ponto de partida foi o momento fundacional de cada organização, quando foram definidas regras, delineados traços identitários e indicados os caminhos a serem seguidos na competição política. As seções seguintes compararam o desenvolvimento organizacional dos partidos analisando eventos/decisões com impacto sobre cada um dos quatro fatores acima relacionados. A sequência de eventos poderia reforçar ou não as características iniciais, ou privilegiar alguns aspectos da vida partidária em detrimento de outros, resolvendo eventuais ambiguidades presentes na fundação.

A análise mostrou que a maneira como os quatro fatores se combinaram fez com que a FA operasse sob condições completamente distintas do PT e do PS. O desenvolvimento organizacional do partido confirmou as marcas de fundação. Ao tomar as decisões de como organizar e conduzir sua organização, os uruguaios assimilaram a necessidade da concertação interna. A origem a partir de organizações pré-existentes (por "difusão territorial") deu ensejo, como esperado por Panebianco (2005), à formação de uma coalizão dominante dispersa que, não obstante, garantiu estabilidade e efetividade ao partido. Os traços fundacionais não apenas permaneceram, como também se reforçaram no curso do desenvolvimento organizacional. Isso possibilitou que o partido chegasse à maturidade com forte participação das bases nas decisões, em uma situação na qual o pluralismo interno conviveu com diferenciações programáticas entre as facções e com um equilíbrio entre setores à direita e à esquerda. O pluralismo foi, ademais, favorecido pela existência de mais de uma liderança que tenha servido de referência, interna e externa, para a vida partidária. $O$ resultado dessa confluência de fatores foi a prevalência de uma dinâmica consociativa e responsiva, o que formatou um quadro de limitada autonomia às lideranças. 
A FA contraria duas noções comuns na literatura. Em primeiro lugar, a tese que anuncia o domínio da "esfera pública" sobre as demais faces dos partidos no atual contexto democrático (Katz and Mair, 1995; 2002). A composição dos governos frenteamplistas reflete o pluralismo interno ao partido. As instâncias partidárias de direção funcionam como um fórum de debate e formulação sempre que as políticas governamentais se mostram polêmicas. Por vezes, o partido balizou definições de governo (Garcé, 2013) e, em algumas ocasiões, fez prevalecer sua posição - como no veto ao tratado de livre comércio com os EUA (Luna, 2010; Lanzaro, 2011), na definição de uma posição pró-aborto e na decisão sobre o Trade in Services Agreement (TISA) ${ }^{27}$. E, em segundo lugar, a tese de que "partidos burocráticos de massa" são fadados a operar com baixa flexibilidade estratégica (Kitschelt, 1994) e enfrentam dificuldades para adequar suas políticas ao ambiente em que atuam. Operando em um contexto de forte participação, procedimentos institucionalizados e expressivo número de veto players, a FA realizou um movimento "al centro y adentro" (Yafeé, 2005) que foi decisivo para a conquista do governo central.

Ainda que no caso dos petistas a comparação, ponto a ponto, aponte para uma situação oposta à da FA, enquanto o mesmo não pode ser dito a respeito dos socialistas chilenos, a distinção entre PT e PS é mais difícil de traçar. Isso se deve ao fato de que nesses dois casos se constata um acentuado grau de autonomia das lideranças - o que os diferencia é o modo como os fatores aqui analisados se combinam.

A trajetória dos socialistas chilenos, tal como na FA, confirma o que foi anunciado por ocasião da reorganização/refundação do partido. Mas nesse caso o sentido é outro: a desmobilização das bases e a convergência programática centrada na preocupação com a governabilidade no período pós-ditadura. Por outro lado, o PS compartilha com os frenteamplistas a situação de pluralismo interno: desde a redemocratização as principais tendências e suas respectivas lideranças se alternam à frente do partido encabeçando amplas coalizões. O efeito do pluralismo sobre a autonomia dos líderes foi, no entanto, mitigado pelo acentuado grau de convergência programática e pela escassa participação das bases nas decisões. O resultado foi a conformação de um partido cartelizado, no qual os acordos firmados não precisam ser submetidos a um escrutínio mais amplo: as principais tendências se acertam "por cima" e bloqueiam as críticas aos rumos do partido. 
Já a relação entre a fundação e o desenvolvimento organizacional do PT se revela mais complexa. Desde o princípio, a proposta era construir um partido, e não uma frente, de modo que a ambiguidade inicial - partidos dentro do partido - teve que ser resolvida. Também o elogio à participação das bases precisou ser "reinterpretado" logo nos primeiros anos. A escolha crucial, feita pelo núcleo fundador, foi a de controlar as zonas de incerteza como condição para a condução do partido. O sucesso nessa empreitada terminou por consolidar uma situação de hegemonia interna. Progressivamente, a direção partidária deixou de ser responsiva a bases que, ao contrário do que aconteceu na FA, nunca chegaram a ter uma participação direta no processo decisório - sua influência foi se fazendo cada vez mais indireta até chegar à militância de "baixa intensidade" no período do PED. Contribuiu para o processo o sucesso institucional, em particular a conquista da Presidência da República. A sequência de vitórias, a partir de então, acelerou a convergência programática e ideológica no interior do partido, isolou as vozes mais à esquerda, e sacramentou Lula como liderança inconteste, fechando o ciclo e legitimando ainda mais o grupo dirigente hegemônico.

Comparado ao PS, o PT mantém uma maior participação interna e conexão com a sociedade civil. O partido ainda existe nas ruas em vez de apenas respirar nas instituições. Mas isso não foi suficiente para se contrapor ao efeito combinado dos outros três fatores. Já no PS, a manutenção do pluralismo interno apenas resultou em um consociativismo pelo alto. Com as ferramentas aqui utilizadas não é possível, portanto, estabelecer uma distinção clara entre os dois partidos no que se refere ao grau de autonomia das lideranças.

Um último ponto merece menção: ao analisar a trajetória do PT "ao centro", Samuels (2004) sustentou que a chave para entender a capacidade de adaptação estratégica do partido estaria em suas instituições internas capazes de gerar responsabilidade da liderança. Uma base crescentemente mais pragmática teria sido o principal fator a influenciar tal movimento, uma vez que a direção partidária carecia de autonomia. Mas ao contrário disso, conforme argumentado aqui, o que se viu foi um círculo dirigente dotado de ampla autonomia. Samuels tem razão ao dizer que o aprendizado institucional teve impacto sobre a base do PT. Mas é certo que, com o escândalo do "mensalão", boa parte dos petistas, completamente aturdidos (não pode ser verdade!), percebeu que havia alguma coisa errada nas escolhas feitas pelos 
dirigentes. O grau de autonomia adquirido pela coalizão dominante havia passado do ponto. Uma década depois, na operação Lavajato, constatou-se que nada havia mudado.

PT, FA e PS realizaram importantes processos de flexibilização estratégica. Programas e políticas de alianças foram modificados. Certamente, as mediações realizadas no Uruguai para a conquista da Presidência da República foram menores que as processadas no Brasil e no Chile. Petistas e socialistas apresentaram trajetórias distintas, mas uma vez no governo tiveram que operar em coalizões nas quais as forças de esquerda eram minoritárias e onde, por vezes, a base governista sequer detinha maioria parlamentar. O PT teve ainda que se aliar a partidos situados à direita do espectro partidário.

Já os frenteamplistas conduziram governos majoritários e unipartidários. Mas isso não os desobrigou de buscar os eleitores dos partidos Nacional e Colorado. O movimento, "al centro y adentro", implicou em readequações programáticas e se realizou sob intenso debate, com ampla participação das bases, diversidade ideológica e disputa entre lideranças. $\mathrm{O}$ caso da FA mostra que movimentos no sentido da moderação programática não necessariamente opõem lideranças pragmáticas a militâncias ideológicas e não precisam ser precedidos por uma ampliação no grau de autonomia das primeiras.

(Recebido para publicação em 21 de novembro de 2019) (Reapresentado em 22 de junho de 2020) (Aprovado para publicação em 27 de julho de 2020)

\section{NOTAS}

1. Ver: <http://www.lr21.com.uy/politica/1387802-plenario-frente-amplio-sendic-de-leon-suspension-almagro-expulsion>. Acesso em 23 de maio de 2020.

2. Para os casos da FA e do PS foram realizadas entrevistas. No primeiro caso, com dirigentes e lideranças dos principais grupos políticos, e no segundo com cientistas políticos e sociólogos chilenos. O campo foi realizado de maio a julho de 2017. No Uruguai foram entrevistados Marcelo Rebolledo (então secretário de organização da FA); Alejandro Sanchéz (deputado e dirigente do Movimiento de Participación Popular); Rafael Michelini (senador e dirigente de Nuevo Espacio); Agustín Canzani (coordenador da Fundação Liber Seregni); Verónica Piñeiro (representante de base eleita por Montevidéu e membro da Comissão Política); Enrique Rubio (dirigente da Vertente Artiguista), Monica Xavier (senadora e dirigente do Partido Socialista Uruguaio); e Eduardo Lorier (dirigente do Partido Comunista do Uruguai). No Chile foram mantidas conversas com Juan Pablo Luna, David Altman, Fernando Rosenblatt, Ricardo Gamboa, Alfredo Joignant, Tomaz 
Monsalve e Fernando Atria (dirigente da Izquerda Socialista). Nas entrevistas o foco foi mantido no desenvolvimento organizacional e, mais especificamente, nos quatro fatores apontados como explicativos para se compreender o grau de autonomia alcançado pelas lideranças partidárias. A pesquisa foi realizada com o auxílio de uma bolsa de produtividade do CNPq.

3. Entrevista com Marcelo Rebolledo em 22/06/2017.

4. Michelini e Sanchéz foram entrevistados nos dias 30/06 e 10/07 de 2017. O estatuto de 1971 encontra-se disponível em: <www.frenteamplio.org.uy>. Acesso em 17 de setembro de 2019.

5. Para a história do PS, consultar: <https://portal.pschile.cl>. Acesso em 17 de setembro de 2019.

6. A FA foi declarada ilegal pela ditadura militar em 1973 e retornou à legalidade em 1984 .

7. Ver: <https://www1.folha.uol.com.br/poder/2016/11/1831502-pt-extingue-processo-de-eleicao-direta-a-presidencia-do-partido.shtml>. Dados para 2017 e 2019 obtidos no site do partido. Para detalhes sobre 2019 consultar: <https:/ / pt.org.br/cen-proclama-o-resultado-da-primeira-etapa-do-7-congresso/>. Acessos em 20 de setembro de 2020.

8. Ver: <https://g1.globo.com/politica/noticia/2019/06/23/tres-em-cada-quatro-partidos-do-pais-tem-mais-da-metade-da-estrutura-formada-por-comissoes-provisorias.ghtml>. Notícia reproduzida no site do PT. Acessos em 20 de setembro de 2019.

9. Ver: <.www.frenteamplio.org.uy>. Acesso em 17 de setembro de 2019.

10. Agustín Canzani, Verónica Piñeiro e Enrique Rubio foram entrevistados respectivamente em 23/06; 05/07 e 07/07 de 2017.

11. Artigos 18 e 19 do estatuto. Disponível em: <.https:/ / portal.pschile.cl/>. Acesso em 17 de setembro de 2019.

12. Artigos 43 do estatuto. Disponível em: <https://portal.pschile.cl/>. Acesso em $17 \mathrm{de}$ setembro de 2019.

13. Cálculo feito pelo autor a partir de dados disponibilizados no site do partido.

14. Lorier e Mónica foram entrevistados em 08 e 09 de julho de 2017.

15. Ver: <https://www.pagina12.com.ar/203626-el-frente-amplio-renueva-su-liderazgo-en-uruguay>. Acesso em 15 de maio de 2020.

16. Nas disputas para as intendências os partidos podem lançar até 03 candidatos (Pérez e Piñeiro, 2016).

17. Entrevistas de Enrique Rubio e Rafael Michelini.

18. São 25 temas com diferentes quóruns para aprovação: 3/5; 2/3; 3/4; 4/5; 9/10 (exclusão ou ingresso de setores) e unanimidade (acordo político e bases programáticas).

19. Fernando Atria (Izquierda Socialista), entrevistado em 05/04/2017.

20. Em especial, Ricardo Gamboa e Alfredo Joignant . 
21. "Comunicado de prensa" liberado pelo partido em 28/05/2019. Ver também: <https:// radio.uchile.cl/2019/05/24/elecciones-del-partido-socialista-proyecto-politico-o-simple-disputa-de-poder/>. Acesso em 23 de setembro de 2019.

22. A Articulação assumiu posteriormente os nomes de "Campo Majoritário" e "Construindo um Novo Brasil", à medida que incorporava agrupamentos menores.

23. A Causa Operária deu origem ao Partido da Causa Operária (PCO). A Convergência assumiu a denominação de Partido Socialista dos Trabalhadores Unificado (PSTU).

24. Além do $\mathrm{CNB}$, os candidatos mais votados pertenciam à Mensagem ao Partido, ao Movimento PT e ao PT de Massas e na Luta (PTML) (Amaral, 2010; Secco, 2018). Também contribuiu para o enfraquecimento da esquerda a saída daqueles que posteriormente constituíram o Partido Socialismo e Liberdade (PSOL).

25. Ver: <https://politica.estadao.com.br/noticias/geral,por-renovacao-na-direcao-do-partido-movimento-muda-pt-se-reune-em-brasilia,10000092358 $>$. Para o resultado da eleição: <https: / /pt.org.br/6o-congresso-nacional-do-pt/ >. Acessos em 23 de setembro de 2019 .

26. Ver: <https://www.bcn.cl/historiapolitica/resenas_parlamentarias/>. Site da Biblioteca Nacional do Congresso nacional do Chile. Acesso em 10 de out. de 2019.

27. Entrevistas com Verónica Piñeiro e Enrique Rubio. Vázquez era favorável à adesão ao TISA (Trade in Services Agreement), mas cedeu à posição do partido e posicionou-se contra a assinatura (Pérez y Piñeiro, 2016). 


\section{REFERÊNCIAS}

ALTMAN, David. (2002), “Cambios en las Percepciones Ideológicas de Lemas y Fracciones Políticas: Un Mapa del Sistema de Partidos Uruguayo (1986-1997)”. Cuadernos Del CLAEH, vol. 24, $\mathrm{n}^{\circ} 85$, pp. 89-110.

AMARAL, Oswaldo. (2010), As Transformações na Organização Interna do Partido dos Trabalhadores entre 1995 e 2009. Tese (Doutorado em Ciência Política), Universidade Estadual de Campinas, São Paulo.

. (2011), "Ainda Conectado: o PT e Seus Vínculos Com a Sociedade". Opinião Pública, vol. 17, nº 1, pp. 1-44.

(2013), “As Transformações nas Formas de Militância no Interior do PT: Maior Inclusão e Menor Intensidade”. Revista Brasileira de Ciências Sociais, vol. 28, nº 82, pp. 67-86.

CHASQUETTI, Daniel. (2007), "Uruguay 2006: Éxitos y Dilemas del Gobierno de Izquierda”. Revista de Ciencia Política, vol. 27, n 1, pp. 249-263.

CHASQUETTI, Daniel; BUQUET, Daniel; CARDARELLO, Antonio. (2013), “La Designación de Gabinetes en Uruguay: Estrategia Legislativa, Jerarquía de los Ministerios y Afiliación Partidaria de los Ministros". América Latina Hoy, vol. 64, pp. 15-40.

CHILE. Biblioteca Nacional del Congreso de Chile. "Camilo Escalona Medina - Reseñas Biográficas Parlamentarias". Disponível em: https:/ / www.bcn.cl/historiapolitica/resenas_parlamentarias/wiki/Camilo_Escalona_Medina. Acesso em 10 de outubro de 2019.

GAMBOA, Ricardo; SALCEDO, Rodrigo. (2009), “El Faccionalismo en el Partido Socialista de Chile (1990-2006): Características y Efectos Políticos en Sus Procesos de Toma de Decisión". Revista de Ciencia Política, vol. 29, n³ 3, pp. 667- 692.

GARCÉ, Adolfo. (2010), “Uruguay 2009: de Tabaré Vázquez a José Mujica”. Revista de Ciencia Política, vol. 30, n 2, pp. 499-535.

. (2013), "Otro Balance del Congreso del Frente Amplio". Analisislatino. Disponível em: https:/ / www.analisislatino.com/opinion/?id=6824. Acesso em 12 de outubro de 2019.

HANDLIN, Samuel; COLLIER, Ruth. (2011) “The Diversity of Left Party Linkages and Competitive Advantages", in S. Levitsky e K. Roberts (eds), The Ressurgence of Latin American Left. Baltimore, The Johns Hopkins University Press, pp. 139-161.

KATZ, Richard, MAIR, Peter. (1993), "The Evolution of Party Organizations in Europe: The Three Faces of Party Organization". American Review of Politics, vol. 14, pp. 593-617.

(2002), "The Ascendancy of the Party in Public Office: Party Organization Change in Twentieth-century Democracies", in R. Gunther, J. Monteiro e J. Linz (orgs.), Political Parties - Old Concepts and New Challenges. Oxford, Oxford University Press, pp. 113-134.

KECK, Margaret. (1991), PT - A Lógica da Diferença: o Partido dos Trabalhadores na Construção da Democracia Brasileira. São Paulo, Ática.

KITSCHELT, Herbert. (1994), The Transformation of European Social Democracy, Cambridge: Cambridge University Press. 
LACERDA, Alan. (2002), “O PT e a unidade partidária como problema”. Dados, vol. 45, n 1 , pp. 39-76.

LANZARO, Jorge. (2001), “El Frente Amplio: un Partido de Coalición, Entre la Lógica de Oposición y la Lógica de Gobierno". Revista Uruguaya de Ciencia Política, nº 12, pp. 35-66.

. (2011), "Uruguay: A Social Democratic Government in Latin America", in S. Levitsky e K. Roberts (eds), The Ressurgence of Latin American Left. Baltimore, The Johns Hopkins University Press, pp. 348-374.

LEVITSKY, Steven. (2005), La Transformación del Justicialismo. Del Partido Sindical al Partido Clientelista 1983-1999. Buenos Aires, Siglo XXI.

LEVITSKY, Steven; ROBERTS, Kenneth. (2011), “Latin America's 'Left Turn': A Framework for Analysis", in S. Levitsky e K. Roberts (eds), The Ressurgence of Latin American Left. Baltimore, The Johns Hopkins University Press, pp. 1-28.

LIJPHART, A. (1971), "Comparative Politics and the Comparative Method". The American Political Science Review, vol. 65, n 3, pp. 682-693.

LUNA, Juan Pablo. (2007), “Frente Amplio and the Crafting of a Social Democratic Alternative in Uruguay". Latin American Politics and Society, vol. 49, nº 4, pp. 1-30.

. (2010), "The Left Turns: Why They Happened and How They Compare", in M. Cameron e E. Hershberg (eds.), Latin America's Left Turns. Colorado: Lynne Rienner Publishers.

(2016), "Chile's Crisis of Representation". Journal of Democracy, vol. 27, n 3, pp. 129-138.

LUNA, Juan Pablo; ROSENBLATT, Fernando. (2012), “¿Notas para una Autopsia? Los Partidos Políticos en Chile", in F. J. Diaz e L. Sierra (eds.) Democracia Con Partidos. Santiago, Centro de Estudios Políticos, pp. 115-268.

MELO, Carlos Ranulfo. (2016), “Da Oposição ao Governo: Uma Análise Comparada das Mudanças Ocorridas no Partido dos Trabalhadores (PT), na Frente Ampla (A) e no Partido Socialista do Chile (PSCh)". Apresentado no $10^{\circ}$ Encontro da Associação Brasileira de Ciência Política. Belo Horizonte, 30 de julho a 02 de agosto.

MELO, Carlos Ranulfo; NUNES, Felipe. (2015), "Political Parties: The Case of Brazil”, in G. Passareli (org.), The Presidentialization of Political Parties. Palgrave McMillan, pp. 67-87.

MENEGUELLO, Rachel. (1989), PT: A Formação de um Partido, 1979-1982. São Paulo: Paz e Terra.

MORAES, Juan Andres; GUEDES, Alejandro; LUJAN, Diego. (2012), “Uruguay: ¿Dónde está el Piloto? A Dos Años del Gobierno Mujica". Revista de Ciencia Política, vol. 32, n 1, pp. 269-291.

MORAES, Juan Andres; LUJAN, Diego. (2016). "The Heft of the Left: Explaining the Frente Amplio's Formation and Change". Panoramas - Scholarly plataform, University of Pittsburgh. Disponível em: https: / / www.panoramas.pitt.edu/news-and-politics/heft-leftexplaining-frente-amplio's-formation-and-change. Acesso em 23 de outubro de 2019.

PANEBIANCO, Angelo. (2005), Modelos de Partido: Organização e Poder nos Partidos Políticos. São Paulo, Martins Fontes. 
PARTIDO DOS TRABALHADORES. (1998), Partido dos Trabalhadores: Resoluções de Encontros e Congressos (1979-1998). São Paulo, FPA.

PEDRABUENA, Bruno Vera. (2012), "Sistema Electoral, Reglas de Decisión y Fraccionalización en el Frente Amplio: Análisis de la Estructura de Oportunidades para las Fracciones". Apresentado no $4^{\circ}$ Congresso Uruguaio de Ciência Política. Montevidéu, 14 a 16 de novembro.

PÉREZ, Verónica; PIÑEIRO, Rafael. (2016), “Uruguay 2015: Los Desafíos de Gobernar por Izquierda Cuando la Economía se Contrae". Revista de Ciencia Política, vol. 36, nº 1, pp. 339-363.

PÉREZ, Verónica; PIÑEIRO, Rafael; ROSENBLATT, Fernando. (2019), How Party Activism Survives: Uruguay's Frente Amplio. Cambridge, Cambridge University Press

PONTE, Germán. (2013), “Uruguay: ¿El Año Bisagra?”. Revista de Ciencia Política, vol. 33, $\mathrm{n}^{\circ} 1$, pp. 351-374.

QUIROGA, Mauricio. (2012), “The Concertación's Defeat in Chile's 2009-2010 Presidential Elections". Latin American Politics and Society, vol. 54, n 2, pp. 79-107.

RENNÓ, Lúcio; CABELLO, Andrea. (2010), “As Bases do Lulismo: a Volta do Personalismo, Realinhamento Ideológico ou não Alinhamento?". Revista Brasileira de Ciências Sociais, vol. $25, \mathrm{n}^{\circ} 74$, pp. $39-60$.

RIBEIRO, Pedro. (2008), Dos Sindicatos ao Governo: a Organização Nacional do PT de 1980 a 2005. Tese (Doutorado em Ciência Política), Universidade Federal de São Carlos, São Paulo.

. (2013). “Organização e Poder nos Partidos Brasileiros: Uma Análise dos Estatutos". Revista Brasileira de Ciência Política, no 10, pp. 225-265.

(2014), "An Amphibian Party? Organisational Change and Adaptation in the Brazilian Workers' Party, 1980-2012". Journal of Latin American Studies, vol. 46, nº 1, pp. 87-119.

ROBERTS, Kenneth. (1995), "From the Barricades to the Ballot Box: Redemocratization and Political Realignment in the Chilean Left". Politics \& Society, vol. 23, n 4, pp. 495-519

ROSE, Richard. (1976), The Problem of Party Government. Harmondsworth, Penguin Books.

ROSENBLATT, Fernando; PIÑEIRO, Rafael; PÉREZ, Verónica. (2016), “Internas del Frente Amplio: Continuidad en un Contexto de Cambios". Revista Nueva Sociedad [online], Disponível em: https://nuso.org/articulo/internas-del-frente-amplio-continuidad-en-un-contexto-de-cambios/. Acesso em 08 de agosto de 2019.

SAMUELS, David. (2004), "From Socialism to Social Democracy". Comparative Political Studies, vol. XX, no X, pp. 1-26.

SAMUELS, David; SHUGART, Matthew. (2010), Presidents, Parties and Prime Ministers. Cambridge, Cambridge University Press.

SAMUELS, David; ZUCCO, Cesar. (2014), "The Power of Partisanship in Brazil: Evidence from Survey Experiments". American Journal of Political Science, vol. 1, nº 58, pp. 212-225.

SARTORI, Giovanni. (2005), Partidos y Sistemas de Oartidos. Madrid, Alianza. 
SCARROW, Susan.; WEBB, Paul; FARREL, David. (2000), “From Social Integration to Electoral Contestation: The Changing Distribution of Power Within Political Parties". in R. Dalton e M. Wattemberg (eds.), Parties Without Partisans. Oxford, Oxford University Press, pp. 633-650.

SECCO, Lincoln. (2018), História do PT. São Paulo, Ateliê.

SINGER, André. (2012), Os Sentidos do Lulismo. São Paulo, Companhia das Letras.

TAMAYO, Victor. (2016), “El Partido Socialista de Chile y la Presente Cultura de Facciones: un Enfoque Histórico Generacional (1973 - 2015)". Izquierdas [Online], n 26. Disponível em: http://izquierdas.revues.org/681, pp. 1-31. Acesso em 20 de janeiro de 2017.

TERRON, Sonia; SOARES, Gláucio. (2010), “As Bases Eleitorais de Lula e do PT: do Distanciamento ao Divórcio". Opinião Pública, vol. 16, n² 2, pp. 310-337.

YAFEÉ, Jaime. (2005), Al Centro y Adentro: La Renovación de la Izquierda y el Triunfo del Frente Amplio en Uruguay. Montevideo, Ediciones Linardi y Risso.

(2013), “Competencia Interna y Adaptación Partidaria en el Frente Amplio de Uruguay". Perfiles Latinoamericanos, vol. 21, n 41, pp. 71-94. 


\section{RESUMO}

Participação, Pluralismo e Autonomia das Lideranças: Partido dos Trabalhadores, Frente Ampla e Partido Socialista do Chile em Perspectiva Comparada

Este artigo compara o Partido dos Trabalhadores (PT), a Frente Ampla (FA) e o Partido Socialista do Chile (PS) no que se refere ao grau de autonomia adquirido por suas lideranças. Para tanto, considera quatro fatores explicativos, todos vinculados ao desenvolvimento organizacional de cada partido: a influência das bases no processo decisório; o balanço de poder entre os diversos grupos no interior de cada partido; a distância ideológica entre esses grupos; e a existência ou não de uma única liderança capaz de servir como ponto de referência e aglutinação do partido. A análise mostra que a maneira como estes fatores se combinaram na trajetória da FA permitiu que o partido mantivesse uma dinâmica consociativa e uma forte responsividade da liderança perante sua base, o que não foi verificado nos outros dois casos.

Palavras-chave: Partidos dos Trabalhadores; Frente Ampla; Partido Socialista do Chile; autonomia das lideranças; desenvolvimento organizacional

\section{ABSTRACT \\ Participation, Pluralism and Autonomy of Leaderships: Workers' Party, Broad Front and Socialist Party of Chile in Comparative Perspective}

This article compares the Workers' Party (PT), the Broad Front (FA) and the Socialist Party of Chile (PS) with regard to the degree of autonomy acquired by their leaders. To this end, it considers four explanatory factors, all linked to the organizational development of each party: the influence of the bases in the decision-making process; the balance of power between the different groups within each party; the ideological distance between these groups; and the existence (or not) of a single leadership capable of serving as the party's point of reference and agglutination of the party. The analysis shows that the way these factors were combined in the FA's trajectory allowed the party to maintain a consociative dynamic and a strong responsiveness of the leadership to its base, which was not the case in the other two parties.

Keywords: Workers' Parties; Broad Front; Chilean Socialist Party; leadership autonomy; organizational development 


\section{RÉSUMÉ}

Participation, Pluralisme et Autonomie de Direction: le Partido do Trabalhadores, la Frente Ampla et le Partido Socialista de Chile dans une Perspective Comparative

Cet article compare le Partido dos Trabalhadores (PT), la Frente Amplio (FA) et le Partido Socialista de Chile (PS) en ce qui concerne le degré d'autonomie acquis par leurs dirigeants. Pour cela, quatre facteurs explicatifs sont considérés, tous liés au développement organisationnel de chaque parti: l'influence des bases dans le processus décisionnel; l'équilibre des pouvoirs entre les différents groupes au sein de chaque parti; la distance idéologique entre ces groupes; et l'existence (ou non) d'une direction unique capable de servir de point de référence et d'agglutination du parti. L'analyse montre que la manière dont ces facteurs ont été combinés dans la trajectoire de la FA a permis au parti de maintenir une dynamique consociative et une forte réactivité du leadership envers sa base.

Mots-clés: Partido dos Trabalhadores; Frente Amplio; Partido Socialista de Chile; autonomie de airection; développement organisationnel.

\section{RESUMEN}

Participación, Pluralismo y Autonomía de los Liderazos: Partido de los Trabajadores, Frente Amplio y Partido Socialista de Chile en Perspectiva Comparada

Este artículo compara el Partido de los Trabajadores (PT), el Frente Amplio (FA) y el Partido Socialista de Chile (PS) en lo que se refiere al grado de autonomía adquirido por sus líderes. Para eso, son considerados cuatro factores explicativos, todos vinculados al desarrollo organizacional de cada partido: la influencia de las bases en el proceso de toma de decisiones, el equilibrio de poder entre los diversos grupos al interior de cada partido, la distancia ideológica entre tales grupos y la existencia (o no) de un único liderazgo capaz de servir como punto de referencia y aglutinación del partido. El análisis muestra que la manera como estos factores se combinaron en la trayectoria del FA permitió que el partido mantuviera una dinámica de consociación y una fuerte sensibilidad del liderazgo frente a su base.

Palabras clave: Partidos de los Trabajadores; Frente Amplio; Partido Socialista de Chile; autonomía de los liderazgos; desarrollo organizacional 